Article

\title{
Antibacterial Activities of Azole Complexes Combined with Silver Nanoparticles
}

\author{
Nestor J. Bello-Vieda ${ }^{1}$ (D), Homero F. Pastrana 2 (D), Manuel F. Garavito ${ }^{3}$, Alba G. Ávila ${ }^{2}$, \\ Adriana M. Celis ${ }^{3}$ (D), Alvaro Muñoz-Castro ${ }^{4}$, Silvia Restrepo ${ }^{3}$ and John J. Hurtado ${ }^{1, *}$ (D) \\ 1 Department of Chemistry, Universidad de los Andes, Carrera 1 No. 18A-12, Bogotá 111711, Colombia; \\ nj.bello1211@uniandes.edu.co \\ 2 Eléctrica y Electrónica, Centro de Microelectrónica, Universidad de Los Andes, Carrera 1 No. 18A-12, \\ Bogotá 111711, Colombia; hf.pastrana122@uniandes.edu.co (H.F.P.); a-avila@uniandes.edu.co (A.G.Á.) \\ 3 Laboratorio de Micología y Fitopatología, Departamento de Ciencias Biológicas, Universidad de Los Andes, \\ Carrera 1 No. 18A-12, Bogotá 111711, Colombia; manuel.garavitodiago@yale.edu (M.F.G.); \\ acelis@uniandes.edu.co (A.M.C.); srestrep@uniandes.edu.co (S.R.) \\ 4 Grupo de Química Inorgánica y Materiales Moleculares, Universidad Autonoma de Chile, \\ El Llano Subercaseaux 2801, Santiago, Chile; alvaro.munoz@uautonoma.cl \\ * Correspondence: jj.hurtado@uniandes.edu.co; Tel.: +57-1-339-4949 (ext. 3468)
}

Received: 4 January 2018; Accepted: 6 February 2018; Published: 8 February 2018

\begin{abstract}
Growing antimicrobial resistance is considered a potential threat for human health security by health organizations, such as the WHO, CDC and FDA, pointing to MRSA as an example. New antibacterial drugs and complex derivatives are needed to combat the development of bacterial resistance. Six new copper and cobalt complexes of azole derivatives were synthesized and isolated as air-stable solids and characterized by melting point analyses, elemental analyses, thermogravimetric analyses (TGA), and infrared and ultraviolet/visible spectroscopy. The analyses and spectral data showed that the complexes had 1:1 (M:L) stoichiometries and tetrahedral geometries, the latter being supported by DFT calculations. The antibacterial activities of the metal complexes by themselves and combined with silver nanoparticles (AgNPs; $2 \mu \mathrm{g} \mathrm{mL}{ }^{-1}$ ) were assessed in vitro by broth microdilution assays against eight bacterial strains of clinical relevance. The results showed that the complexes alone exhibited moderate antibacterial activities. However, when the metal complexes were combined with AgNPs, their antibacterial activities increased (up to 10-fold in the case of complex 5), while human cell viabilities were maintained. The minimum inhibitory concentration $\left(\mathrm{MIC}_{50}\right)$ values were in the range of $25-500 \mu \mathrm{g} \mathrm{mL}^{-1}$. This study thus presents novel approaches for the design of materials for fighting bacterial resistance. The use of azole complexes combined with AgNPs provides a new alternative against bacterial infections, especially when current treatments are associated with the rapid development of antibiotic resistance.
\end{abstract}

Keywords: azole ligands; copper and cobalt complexes; silver nanoparticles; antibacterial resistance; antibacterial activity; cytotoxicity

\section{Introduction}

The bioactivity of some metal nanoparticles and their uses in diagnostic sensors are research areas of growing interest [1]. Nanosized metal particles show notable physical, chemical and biological properties compared with bulk solids [2]. Silver nanoparticles (AgNPs) have attracted the interest of the scientific community because silver has been used as an antiseptic and antimicrobial against different species of bacteria [1,2]. The growing resistance of pathogenic bacterial and fungal strains to traditional treatments is another key factor driving research with this type of material. In recent years, the effectiveness of some nanoconjugates has been demonstrated against some pathogenic microbes, 
showing great potential for nanomedicine. The combination of antibiotics, antifungal agents such as azoles, metal complexes and nanoparticles could increase the efficiency of drugs, even against drug-resistant pathogens [3,4].

AgNPs have been used in recent years for the production of a new class of antimicrobials to combat a widespread range of pathogens. Even though there have been several studies showing the high antibacterial effect of AgNPs, their mechanism of action is not fully understood [5]. The broad activity spectrum of AgNPs against morphologically and metabolically diverse microorganisms could be related to a complex and multilayered mechanism of action. Several mechanisms have been proposed and include the alteration of cell walls and cytoplasm. Among these mechanisms are the membrane permeability increase and respiration depletion, morphological changes of the cytoskeleton, the separation of the cytoplasmic membrane from the cell wall, and plasmolysis and inhibition of bacterial DNA replication [2]. Nevertheless, the high bactericidal activity is related to doses over $40 \mu \mathrm{g} \mathrm{mL} \mathrm{m}^{-1}$, but these doses have been reported as cytotoxic in mammalian cells by Zhang et al. [6] and toxic on aquatic organisms such as algae by Sass et al. [7]. Better antibacterial activity with low AgNP loadings can be achieved by the addition of compounds with low resistance such as metal azole complexes, limiting the potential toxicity of nanoparticles. These compounds are produced using a metallic salt and an appropriate ligand with chelating properties. The use of azole derivatives as a ligand is an interesting approach because azoles have antifungal and antibacterial activities [8]. These activities are related to their ability to bind readily to enzymes and receptors in biological systems. When the azole ligand is coordinated to $\mathrm{Co}^{\mathrm{II}}$ or $\mathrm{Cu}^{\mathrm{II}}$, these complexes have higher antimicrobial activity than the free ligand, and in some cases, they exceed that of standard test substances [9-12].

The combined activity of metal complexes and nanoparticles against bacteria has not been assessed yet and could be an interesting approach for utilizing lower azole concentrations for antibacterial activity. In this work, we report the synthesis and characterization of new air-stable cobalt(II) and copper(II) complex derivatives of azoles and their antibacterial activities alone and in combination with AgNPs, which resulted in increased activity.

\section{Discussion}

Complexes 1-4 and 9 and 10 (Scheme 1) have been reported previously (see the Materials and Methods and Supporting Information). The key point in the synthesis of new complexes 5-8, 11 and 12 was the choice of a suitable solvent for each reaction. The reactions were carried out in solvents that dissolved both the ligand and the $\mathrm{MCl}_{2}$ but did not solubilize the final complex. In the synthesis of 5 , 7 and 11, various solvents were tested, i.e., ethanol, methanol (MeOH), acetone, tetrahydrofuran (THF) and acetonitrile $\left(\mathrm{CH}_{3} \mathrm{CN}\right)$, which dissolved the starting reactants. However, no reaction was observed immediately. The cobalt complexes were isolated as air-stable blue, non-hygroscopic solids. The syntheses of the copper complexes were carried out under mild conditions with yields of 44-91\%.

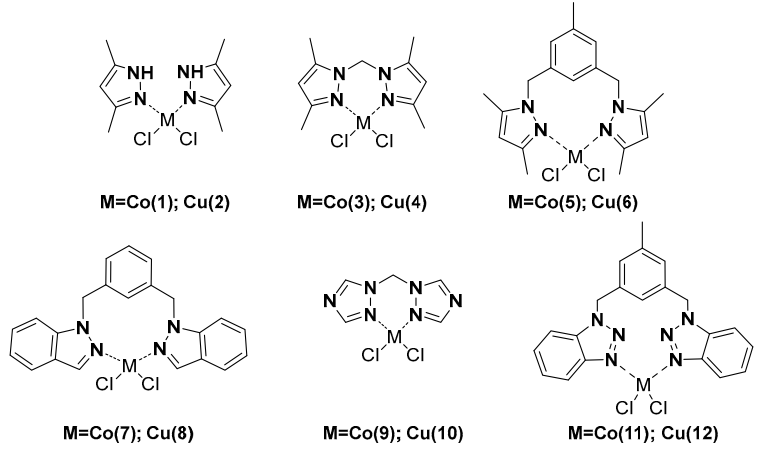

Scheme 1. Azole complexes. 


\subsection{Infrared Spectroscopy}

The new complexes were analyzed by infrared spectroscopy, particularly looking for the band shifts due to metal coordination. Table 1 provides an overview of the main bands in the infrared spectra of the complexes. The bands were assigned considering previous reports of the ligands and similar complexes [8]. In complexes (1 and 2), the presence of the bands at $3344 \mathrm{~cm}^{-1}$ and $3265 \mathrm{~cm}^{-1}$, which are assigned to $\mathrm{N}-\mathrm{H}$ vibrations, confirmed the coordination of the metals to the N2 of 3,5-dimethylpyrazole. We found a shift to higher wavenumbers with respect to the free ligand [8], indicating the rigidity of the molecule when the metal was present. In ( 3 and 4 ), the ring vibrations of $(C=N)$ and (C-C)Pyr in the free ligand $\left(1035 \mathrm{~cm}^{-1}\right.$ and $970 \mathrm{~cm}^{-1}$, respectively) also showed the rigidity of the structure of the complex. This case was not present in complexes (5-8), where the ring vibrations were not affected by coordination likely because the ligand was too big, and the central rings were not influenced by the electron density of the metal. Variations in the infrared spectra of each complex were observed, showing the electronic differences of the corresponding metals. Additionally, it was possible to find $\mathrm{M}-\mathrm{Cl}$ vibrations with very low intensities.

Table 1. Main bands in the FTIR spectra for the complexes. Pyr = pyrazole; Ind = indazole; Tol = toluene; $\mathrm{vs}=$ very strong; $\mathrm{s}=$ strong; $\mathrm{m}=$ medium; $\mathrm{w}=$ weak; $\mathrm{vw}=$ very weak.

\begin{tabular}{cccccc}
\hline Compound & \multicolumn{5}{c}{ Wavenumber $\mathbf{v}\left(\mathbf{c m}^{-\mathbf{1}}\right)$} \\
\hline & $(\mathrm{N}-\mathrm{H})$ & $(\mathrm{C}-\mathrm{H})$ & $(\mathrm{C}-\mathrm{H})_{\mathrm{Pyr}}$ & $(\mathrm{C}-\mathrm{N})$ & $(\mathrm{M}-\mathrm{Cl})$ \\
1 & $3344 \mathrm{~s}$ & $3142 \mathrm{w}$ & $1568 \mathrm{vs}$ & $1470 \mathrm{~m}$ & $427 \mathrm{~m}$ \\
2 & $3265 \mathrm{vs}$ & $3147 \mathrm{vs}$ & $1570 \mathrm{vs}$ & $1472 \mathrm{~m}$ & $431 \mathrm{~m}$ \\
\hline & $(\mathrm{C}-\mathrm{H})$ & $\left(\mathrm{C}-\mathrm{CH}_{3}\right)$ & $(\mathrm{C}=\mathrm{N})$ & $(\mathrm{C}-\mathrm{C})_{\mathrm{Pyr}}$ & $(\mathrm{M}-\mathrm{Cl})$ \\
3 & $3011 \mathrm{w}$ & $1465 \mathrm{~s}$ & $1051 \mathrm{~m}$ & $1003 \mathrm{~m}$ & $493 \mathrm{w}$ \\
4 & $3027 \mathrm{w}$ & $1467 \mathrm{~s}$ & $1044 \mathrm{~m}$ & $1001 \mathrm{~m}$ & $492 \mathrm{w}$ \\
\hline & $(\mathrm{C}-\mathrm{H})$ & $\left(\mathrm{C}-\mathrm{CH}_{3}\right)$ & $(\mathrm{C}-\mathrm{C})_{\mathrm{Pyr}}$ & $(\mathrm{C}-\mathrm{C}-\mathrm{N})$ & $(\mathrm{M}-\mathrm{Cl})$ \\
5 & $3127 \mathrm{~m}$ & $1468 \mathrm{~m}$ & $1608 \mathrm{~m}$ & $729 \mathrm{~m}$ & $419 \mathrm{w}$ \\
6 & $3137 \mathrm{w}$ & $1469 \mathrm{~m}$ & $1608 \mathrm{~m}$ & $738 \mathrm{~m}$ & $420 \mathrm{w}$ \\
\hline & $(\mathrm{C}-\mathrm{H})$ & $(\mathrm{C}-\mathrm{C})_{\text {Ind }}$ & $(\mathrm{C}-\mathrm{N})_{\text {Ind }}$ & $(\mathrm{C}-\mathrm{H})_{\mathrm{Ind}}$ & $(\mathrm{M}-\mathrm{Cl})$ \\
7 & $3094 \mathrm{~m}$ & $1628 \mathrm{~s}$ & $1519 \mathrm{~s}$ & $1478 \mathrm{~m}$ & $490 \mathrm{w}$ \\
8 & $3098 \mathrm{~m}$ & $1628 \mathrm{~s}$ & $1519 \mathrm{~s}$ & $1477 \mathrm{~m}$ & $497 \mathrm{w}$ \\
\hline & $(\mathrm{C}-\mathrm{H})$ & $\left(\mathrm{H}_{2} \mathrm{C}-\mathrm{N}\right)$ & $(\mathrm{N}-\mathrm{N})$ & $(\mathrm{C}-\mathrm{N})$ & $(\mathrm{M}-\mathrm{Cl})$ \\
9 & $3115 \mathrm{w}$ & $1518 \mathrm{~s}$ & $1458 \mathrm{~m}$ & $1362 \mathrm{w}$ & $507 \mathrm{vw}$ \\
10 & $3137 \mathrm{~s}$ & $1525 \mathrm{~s}$ & $1460 \mathrm{~m}$ & $1357 \mathrm{w}$ & $503 \mathrm{vw}$ \\
\hline & $(\mathrm{C}-\mathrm{H})$ & $(\mathrm{C}-\mathrm{C})_{\mathrm{Tol}}$ & $(\mathrm{N}-\mathrm{N})$ & $(\mathrm{N}=\mathrm{N})$ & $(\mathrm{M}-\mathrm{Cl})$ \\
11 & $2970 \mathrm{w}$ & $1610 \mathrm{~m}$ & $1284 \mathrm{~m}$ & $1229 \mathrm{~s}$ & $419 \mathrm{w}$ \\
12 & $2968 \mathrm{~m}$ & $1610 \mathrm{~m}$ & $1288 \mathrm{~m}$ & $1233 \mathrm{~s}$ & $419 \mathrm{w}$ \\
\hline
\end{tabular}

\subsection{UV-Vis Spectroscopy}

The UV-Vis spectra were recorded to study the electronic properties of the complexes and to relate the properties to possible structures. Most of the complexes obtained showed intense absorption bands (200-300 nm). In complex 9, bands below $300 \mathrm{~nm}$ were not observed because the solvent showed a high absorbance in this zone. Such bands are attributed to metal to ligand charge transfer, and intra ligand $\pi-\pi^{*}$ transitions [13]. The cobalt complexes showed a blue color in the solid state. When dissolved in DMSO or $\mathrm{CH}_{3} \mathrm{CN}$, this color remained, while if they were dissolved in $\mathrm{MeOH}$ (complex 7) the color changed to pale pink, a characteristic color of octahedral cobalt complexes with coordinated water. Complexes 1, 9 and 11 showed bands at $600-700 \mathrm{~nm}$, corresponding to ${ }^{4} A_{2 \mathrm{~g}} \leftarrow{ }^{4} T_{2 \mathrm{~g}}$ and ${ }^{4} A_{2 \mathrm{~g}} \leftarrow{ }^{4} T_{1 \mathrm{~g}}[14]$.

Complexes 3 and 5 showed a third band in the visible region with higher energy. This band is related to an equilibrium between tetrahedral and octahedral geometries given by coordination with solvents $\mathrm{H}_{2} \mathrm{O}$ or $\mathrm{CH}_{3} \mathrm{CN}$. In complex 7 , a band at $525 \mathrm{~nm}\left(\varepsilon=17 \mathrm{M}^{-1} \mathrm{~cm}^{-1}\right)$ was observed, which is consistent with $\mathrm{Co}(\mathrm{II})$ octahedral complexes [14]. 
For the $\mathrm{Cu}(\mathrm{II})$ complexes, charge-transfer bands were observed with high intensity in the UV region of the spectra that could be related with transitions of the organic moiety in the complex and to charge transfer from the nonbonding orbital of chloride to the vacant copper(II) d orbitals [15].

Additionally, overlapped signals were found due to interelectronic repulsion. In the case of complexes 4 and 6, it is possible to assign the signals near $300 \mathrm{~nm}$ to charge transfer between chloride and copper. In the visible region near $500 \mathrm{~nm}$, the electronic transition of $t_{2 \mathrm{~g}} \leftarrow e_{\mathrm{g}}$ was found, which is characteristic for $d^{9}$ metals [16].

\subsection{Theoretical Calculations}

Despite several attempts, no crystals suitable for X-ray diffraction analysis were obtained. Further computational studies were carried out for the new complexes to support the characterized structures. The calculated data are given on supporting information, which agrees well to the discussed main bands in the FTIR and UV-Vis spectra and their assignation (see above). For 5-8, 11 and 12, a doublet ground state was obtained (i.e., one unpaired electron).

All the complexes exhibit a slightly distorted tetrahedral geometry. Thus, all the series can be ascribed as tetrahedral complexes of $\mathrm{Co}(\mathrm{II})$ and $\mathrm{Cu}(\mathrm{II})$. Mostly of the upaired electron resides in the $-\mathrm{CoCl}_{2}$ and $-\mathrm{CuCl}_{2}$ fragment according to the obtained spin-denisty. The resulting structures support the expected systems according to the employed ligand. Such structures, exhibits isostructural species between $\mathrm{Co}(\mathrm{II})$ and $\mathrm{Cu}$ (II), which can be viewed as a useful template for further evaluation of relationship between different metal centers and molecular properties.

Moreover, the location of the $-\mathrm{MCl}_{2}$ fragment in relation to the central phenyl ring is shifted between 5-8 and 11, 12, which can be a useful ability to design further selective catalytic species (Scheme 2).

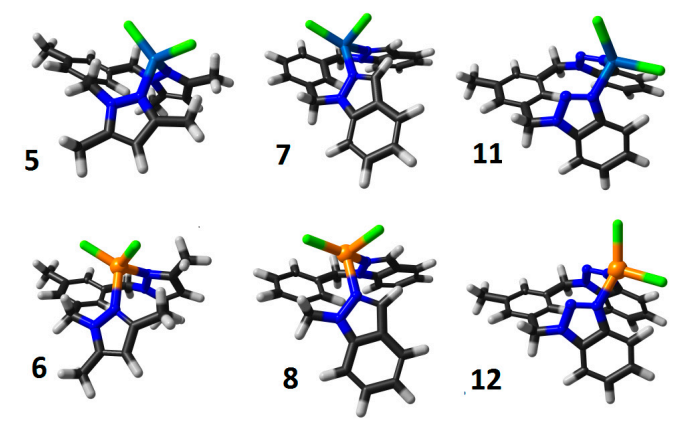

Scheme 2. Optimized geometries for 5-8, 11 and 12, from computational calculations in agreement to Scheme 1.

\subsection{Thermal Analysis}

Thermogravimetric analyses were performed to study the different mass losses and to relate these losses to possible structures. The mass losses are based only on the percentages observed in the thermograms because the study was carried out without a detection system (TGA-MS). Complex 1 showed high stability because a residue at the end of the analysis was observed (pyrazole-Co). Complex (2) showed low thermal stability with $75 \%$ loss of the metal and $40 \%$ total loss of mass at $600{ }^{\circ} \mathrm{C}$. In 3 and 4 rapid thermal degradations were observed in a few steps, indicating that stable intermediates were generated. Complexes 5 and 6 lost nearly $70 \%$ of the total mass at the end of the analysis, and complex 5 showed a very small loss $(1.6 \%)$ at $150{ }^{\circ} \mathrm{C}$, which could be related to the loss of water molecules coordinated to cobalt. However, the IR spectrum did not show bands related to $\mathrm{H}_{2} \mathrm{O}$, so we assume that the mass loss corresponds to $\mathrm{HCl}$. For complex 6 , the total loss of the ligand was observed at $700{ }^{\circ} \mathrm{C}$. Complexes 7 and 8 exhibited good thermal stability with retention of almost half of the initial mass at $700{ }^{\circ} \mathrm{C}$ with observed losses of the indazole ring and $2 \mathrm{HCl}$. Four mass losses were observed for complex $\mathbf{8}$, which were analyzed in three different steps: first, a loss of $2 \mathrm{HCl}$; 
then, a loss of benzene; and finally, decomposition of one indazole group. The mass losses of complex 9 were associated with the splittings of the $\mathrm{CH}_{2}$ spacers and triazoles.

\subsection{Characterization of $A g N P s$}

\subsubsection{Atomic Force Microscopy (AFM)}

The nanoparticle size, size distribution and shape were measured using AFM. The AgNPs were coated with polyvinylpyrrolidone (PVP) and dried without sonication to mimic the methodology in the culture plates. Our results show spherical nanoparticles (Figure 1A,B). The AgNPs agglomerated on clusters up to $50 \mathrm{~nm}$, due to the surface charge of the nanoparticles. Nevertheless, the average height of the single nanoparticles was $8.35 \mathrm{~nm}$, with a height distribution between 5 to $13 \mathrm{~nm}$ (Figure 1B). These results suggest that the sized of the tested nanoparticles are in the range with the more effective antibacterial properties according with the literature [17,18].

\subsubsection{Dynamic Light Scattering (DLS)}

We calculated the Z-potential ( $\delta$ ) from the electrophoretic mobility measurements and the Henry equation as shown in Equation (1):

$$
U_{E}=\frac{2 \varepsilon \zeta f(k a)}{3 \eta}
$$

where $U_{E}$ is the electrophoretic mobility, $\zeta$ is the z-potential, $\varepsilon$ dielectric constant, $f(k a)$ is the Henry's function and $\eta$ is the solution viscosity [19]. Our Z-potential results evidenced that the AgNPs had positively charged surfaces of $18 \pm 3.6 \mathrm{mV}$ in water, as shown in Figure 1D. The Z-potential is correlated to the impact of the bio-interactions of the nanoparticles, specifically with cellular uptake and protein adsorption. Nanoparticles with a positively charged surface are more susceptible to conformations of the protein corona and could be more easily taken in by cells [20]. Positively charged particles have been reported to exert antimicrobial effects by adhering to Gram-negative bacteria [21]. Therefore, we expected more of an antibacterial effect from the 10-nm AgNPs on Gram-negative strains than on Gram-positive strains.

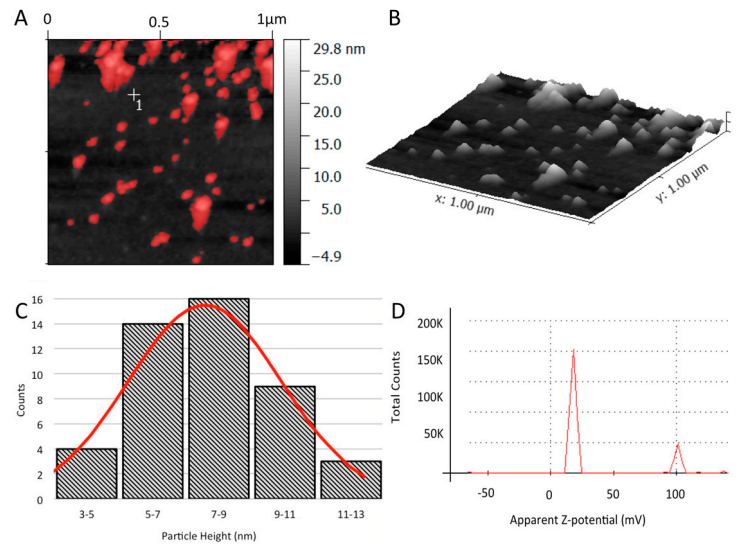

Figure 1. AgNPs characterization. (A) AFM image of the nanoparticles dispersed on silica glass; (B) 3D reconstruction of the AFM image; (C) Size distribution of the nanoparticles by height; (D) Z-potential measurements using DLS. These nanoparticles exhibited a small positively charged potential of approximately $18 \pm 3.6 \mathrm{mV}$. There was also a secondary peak at $100 \mathrm{mV}$ corresponding to the free PVP coating. 


\subsection{Biological Activity}

The biological activity of the AgNPs alone, azole complexes without AgNPs and the azole complexes combined with AgNPs were evaluated in triplicate against eight bacterial strains, MRSA, S. typhimurium, E. aerogenes, B. cereus, E. faecalis, S. flexneri, S. aureus and E. coli, after $8 \mathrm{~h}$ and $16 \mathrm{~h}$ of exposure.

\subsubsection{Antibacterial Activity of the AgNPs Only}

The antibacterial activities of AgNPs have been reported, and it has been shown that their size, and concentration define their effectiveness. Nanoparticles with sizes from 5 to $100 \mathrm{~nm}$ at a concentration of $40 \mu \mathrm{g} \mathrm{mL}^{-1}$ have been reported to have bactericidal effects on most tested strains [22]. Sizes under $30 \mathrm{~nm}$ are more active than bigger nanoparticles, and it is thought that the activity is associated with an easier release of silver ions from the smaller particles [17]. At the same time, particles with spherical shapes show better results, almost five times more effective than particles with different shapes [22,23]. Our experiments were limited to spherical AgNPs with sizes of $10 \mathrm{~nm}$ at $2 \mu \mathrm{g} \mathrm{mL}{ }^{-1}$ concentration. Additional experiment with nanoparticles sizes between 30 and $100 \mathrm{~nm}$ did not show bactericidal effects, data not showed. The concentration of $2 \mu \mathrm{g} \mathrm{mL}{ }^{-1}$ was used to evaluate the synergistic effect with the azole complexes, since the literature reports only bacteriostatic effects at this concentration [2,22]. Therefore, any bactericidal effects depend on the AgNP-Azole complex synergy exclusively. In fact, all the strains in our experiments showed bacteriostatic effects at this concentration (Figure 2).

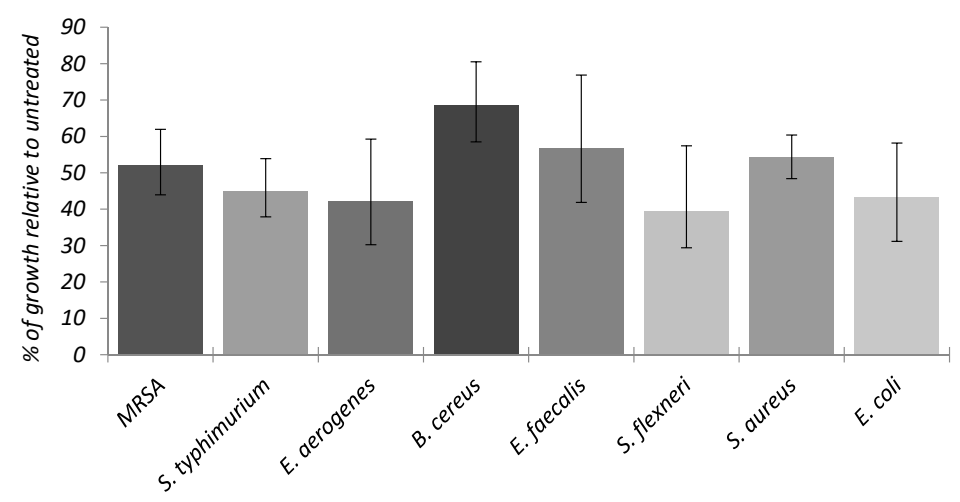

Figure 2. Antibacterial effects of AgNPs alone on four Gram (+) and four Gram (-) strains. The AgNPs's size were $10 \mathrm{~nm}$ at $2 \mu \mathrm{g} \mathrm{mL}-1$.

Bacteria were able to keep growing even in the presence of $2 \mu \mathrm{g} \mathrm{mL} \mathrm{m}^{-1}$ AgNPs. However, at the same time, none of the strains were able to grow at $100 \%$ compared to the untreated control. Some bacteria were more sensitive to the AgNPs, such as E. aerogenes, S. typhimurium, S. flexneri and E. coli. Interestingly, and in contrast with previous studies that reported that AgNPs had a major bactericide effect against gram-negative bacteria [21], we found that the AgNPs showed similar activity against both Gram-positive and Gram-negative bacteria strains. This is most likely because $\mathrm{Ag}^{+}$ ions react strongly with biological substances, such as proteins, enzymes, DNA, and RNA, due to the interactions that occur with thiol, carboxylate, phosphate, hydroxyl, imidazole, indole or amine functional groups. These interactions can be produced simply or in combination, which can lead to a series of events that interfere with vital microbial processes [24]. It has also been reported that silver reacts with the sulfhydryl (-S-H) groups on cell walls to form R-S-S-R bonds, thus, blocking respiration and causing cell death [17].

\subsubsection{Antibacterial Activity of the Azole Complexes with and without AgNPs}

The antibacterial activities of the ligands, its complexes and metal complexes combined with AgNPs against the bacterial strains were also studied. The free ligands showed no activity against 
any bacterium. This may be because azoles have higher anti-fungal activities since they inhibit the ergosterol synthesis in fungal cell walls $[25,26]$. However, some azole-derivative compounds have exhibited moderate antimicrobial activities [27-30], and it has been found that azoles in bacteria are inhibitors for enoyl acyl carrier protein reductase [31]. Manganese tricarbonyl coordinated to ketoconazole, miconazole, or clotrimazole showed higher antibacterial activity compared to the free azole only for Gram-positive bacteria [32].

We studied the antibacterial activities of twelve complexes derived from azole, which contained cobalt and copper. In previous studies carried out in our research group, it was found that metal complexes containing copper and cobalt instead of zinc displayed better antibacterial effects against bacterial strains [8]. The in vitro antibacterial results of complexes 3-5, 8 and 9 with and without AgNPs are summarized in Tables 2 and 3.

As observed in Tables 2 and 3, complexes 3-5, 8 and 9 showed high antibacterial activities. The results suggest that these compounds at 8 and $16 \mathrm{~h}$ were effective against at least one of the strains tested in this study. This finding is likely related to the better solubility, bioavailability and lipophilicity of the complexes that reduced the permeability barriers of the cells and slowed the normal cellular processes of the microorganisms, resulting in increased antimicrobial activities or chelating effects [8,31-33]. At $16 \mathrm{~h}$, better sensitivities to the bacteria for all the azole complexes were observed (Table 3). However, the doses required to generate bactericidal effects were increased for complexes 5 (S. aureus and MRSA) and 3 (MRSA and E. faecalis), which is one of the bacterium that is indicated by the CDC as a serious threat (Tables 2 and 3). The complexes inhibited higher activities against Gram-negative strains than Gram-positive strains. If we compare complexes 3 and $\mathbf{4}$, where only the metal center differs in their structures, complex 3 showed higher antimicrobial activity. This might be attributed to the presence of cobalt. Cobalt has been reported to be a more toxic element than copper [34]. Co has a larger atomic radius than $\mathrm{Cu}$, and it has been reported that the bond length between $\mathrm{Co}$ and its ligand could favor antibacterial activity [35]. In addition, copper is an essential trace element for many biological processes [36]. As the data analysis further indicates, complexes 5, 8 and 9 showed more moderate activities than 3 and 4 . It appears that the presence of the pyrazole ring favors antibacterial activity compared to complexes containing indazole or triazole. Some studies have shown that pyrazoles in complexes can inhibit DNA gyrase and topoisomerase IV in bacteria but are more effective against Gram-positive bacteria than Gram-negative bacteria [37]. The binding of specific metal ions to azoles contributes to the antibacterial activity.

In addition, the combination of AgNPs with the metal complexes showed bactericidal effects at lower concentrations than in the absence of AgNPs for both Gram-positive and Gram-negative bacteria strains. The combination of metal complexes with AgNPs showed bactericidal activities while the free complexes and AgNPs alone just had bacteriostatic effects.

When complex 5 was combined with AgNPs, a 10-fold increase in antimicrobial activity was observed for S. aureus (Table 2), whereas in the case of S. flexneri, E aerogenes and S. typhymurium, we only observed a 2-fold increase in activity. Interestingly, this complex showed better biological results against Gram-negative bacteria, probably due to the presence of toluene, which is known to induce increased fluidity in Gram-negative cell membranes [8].

Complex 8 in the presence of AgNPs showed 3-fold increased activities against S. aureus and E. aerogenes (Table 2). Likewise, in the case of 4 with AgNPs, 2-fold increased activities against $S$. flexneri and E. faecalis were evidenced. Compounds $\mathbf{3}$ and $\mathbf{9}$ showed synergistic antibacterial effects but in minor proportions. These results may be due to the fusion of two antimicrobial agents with distinct modes of action, the chelating effect of the complexes and the presence of $\mathrm{Ag}^{+}$ions (AgNPs), that react with DNA and enzymes of bacteria. To the best of our knowledge, the antibacterial activities of AgNPs combined with azole complexes have not been previously reported. Additionally, the antibacterial activity of AgNPs $(10 \mathrm{~nm})$ at a concentration of $2 \mu \mathrm{g} \mathrm{mL} \mathrm{m}^{-1}$ has not been reported. 
Table 2. Minimum inhibitory concentrations (MIC) ${ }^{\mathbb{I}}$ ) and minimum bactericidal concentrations (MBC, $\mu \mathrm{g} \mathrm{mL}{ }^{-1}$ ) of bacterial strains exposed to azole complexes and 10-nm AgNPs $\left(2 \mu \mathrm{g} \mathrm{mL}^{-1}\right)$ for $8 \mathrm{~h}$.

\begin{tabular}{|c|c|c|c|c|c|c|c|c|c|c|}
\hline \multirow[b]{2}{*}{ Bacteria Strain } & \multicolumn{2}{|c|}{3} & \multicolumn{2}{|c|}{4} & \multicolumn{2}{|c|}{5} & \multicolumn{2}{|c|}{8} & \multicolumn{2}{|c|}{9} \\
\hline & $\begin{array}{l}\text { Without } \\
\text { AgNPs }\end{array}$ & $\begin{array}{c}\text { With } \\
\text { AgNPs * }\end{array}$ & $\begin{array}{l}\text { Without } \\
\text { AgNPs }\end{array}$ & $\begin{array}{c}\text { With } \\
\text { AgNPs * }\end{array}$ & $\begin{array}{l}\text { Without } \\
\text { AgNPs }\end{array}$ & $\begin{array}{c}\text { With } \\
\text { AgNPs * }\end{array}$ & $\begin{array}{l}\text { Without } \\
\text { AgNPs }\end{array}$ & $\begin{array}{c}\text { With } \\
\text { AgNPs * }\end{array}$ & $\begin{array}{l}\text { Without } \\
\text { AgNPs }\end{array}$ & $\begin{array}{c}\text { With } \\
\text { AgNPs * }\end{array}$ \\
\hline S. aureus (+) & $>500$ & $>500$ & 200 II & 200 & 250 & 25 & 200 & 62.5 & 400 II & 250 II \\
\hline S. flexneri $(-)$ & 200 & 125 & 200 & 100 & 200 & 62.5 & 125 & 100 & 250 & 250 \\
\hline MRSA (+) & 62.5 & 62.5 & 250 & 200 & 200 II & 200 & 200 & 250 & $>500$ & $\mathrm{~N} / \mathrm{A}$ \\
\hline E. faecalis $(+)$ & 62.5 I & 100 & 400 & 200 & 250 II & 250 I & 400 & 400 & $>500$ & N/A \\
\hline E. aerogenes (-) & $>500$ & $>500$ & $>500$ & 400 & 400 & 250 & 400 & 250 & $>500$ & 500 II \\
\hline B. cereus $(+)$ & $>500$ & $>500$ & 400 & 400 & $>500$ & $>500$ & 500 II & 400 II & $>500$ & $>500$ \\
\hline E. $\operatorname{coli}(-)$ & 125 & 125 & $>500$ & 500 & 400 & 400 & 500 & 500 & $>500$ & 250 \\
\hline S. typhymurium (-) & $250 \pi$ & 250 II & $\mathrm{N} / \mathrm{A}$ & 250 II & 400 & 250 & 400 II & 400 II & N/A & 500 II \\
\hline
\end{tabular}

* AgNPs with a 10-nm diameter were added at the same concentration of $2 \mu \mathrm{g} \mathrm{mL}{ }^{-1}$; II Bacteria exhibited only inhibitory activities.

Table 3. Minimum inhibitory concentrations (MIC) ${ }^{\mathbb{I}}{ }^{\mathbb{I}}$ and minimum bactericidal concentrations (MBC, $\mu \mathrm{g} \mathrm{mL}^{-1}$ ) of bacterial strains exposed to azole complexes and 10-nm AgNPs $\left(2 \mu \mathrm{g} \mathrm{mL}^{-1}\right)$ for $16 \mathrm{~h}$.

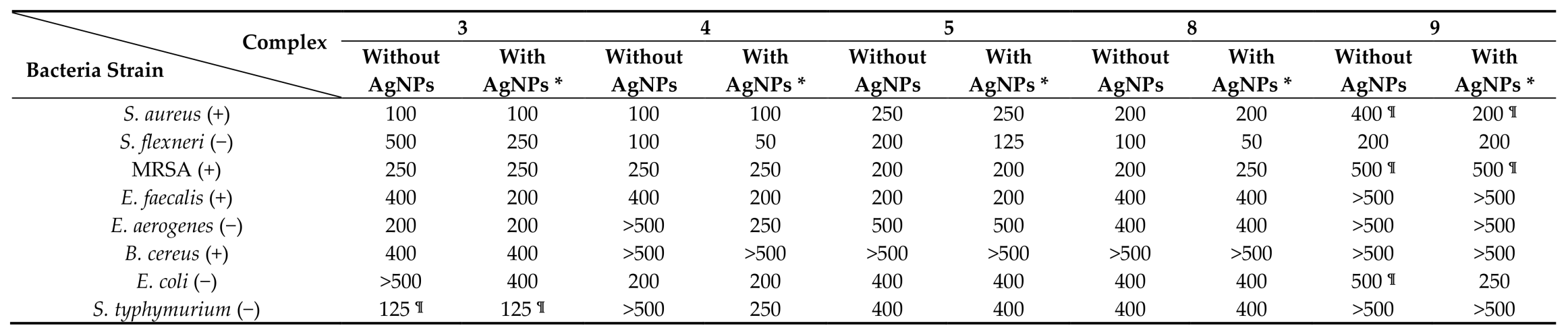

* AgNPs with a 10-nm diameter were added at the same concentration of $2 \mu \mathrm{g} \mathrm{mL}{ }^{-1}$; II Bacteria exhibited only inhibitory activities. 


\subsection{Physicochemical Characterization of the Colloids}

In Figure 3, it is can be seen that AgNPs have their highest absorbance between $417 \mathrm{~nm}$ and $678 \mathrm{~nm}$, while complex 9 has a maximum absorbance at $516 \mathrm{~nm}$.

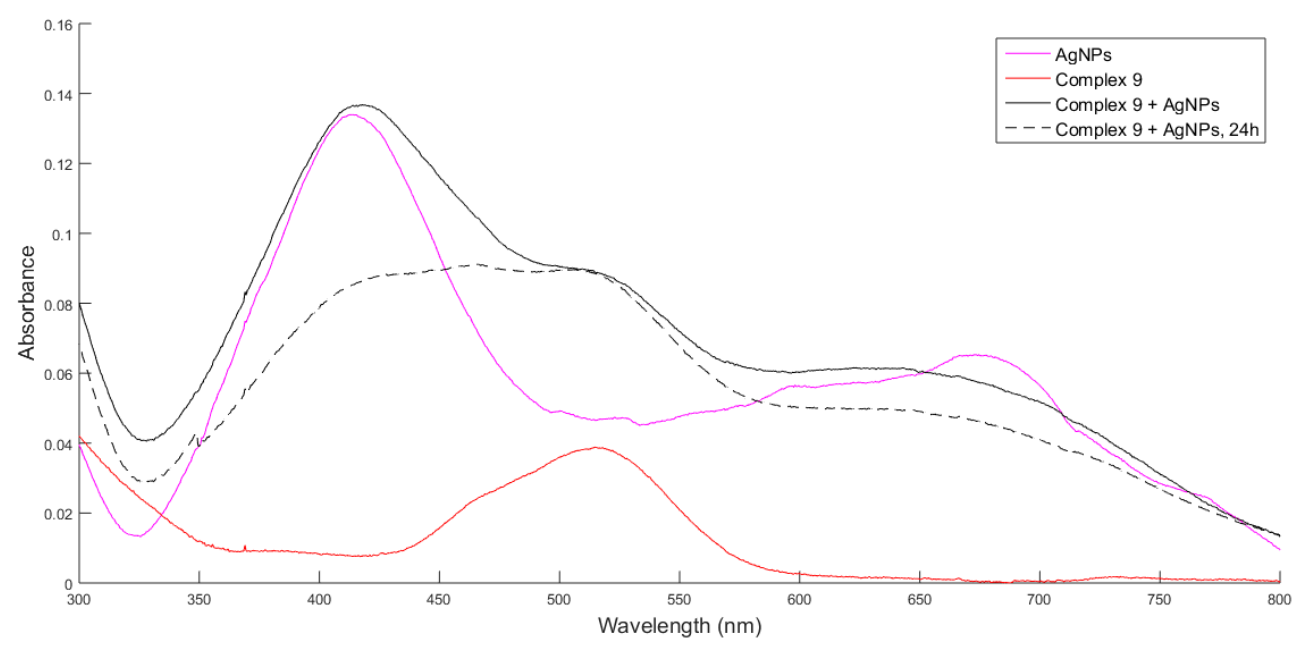

Figure 3. UV/Vis spectra to show the interaction between complex 9 and AgNPs.

The spectrum of the solution with complex 9 and the AgNPs seems to be the sum of the absorbance of each component, with a slightly change in 650-750 nm range. However, when the spectra was recorded $24 \mathrm{~h}$ later, the absorption due to nanoparticles decreased significantly, probably because the complex molecules were adsorbed over the surfaces of the AgNPs. Additionally, there is no change in the absorbance wavelength of the components, suggesting that there is no change in nanoparticle size and that the metal centers of the complexes have no effect on absorbance. These suggest that the interaction between the azol complexes and AgNPs are just physical, without a change in the structure of the coordination compound or the nanoparticles.

The results suggest that the presence of AgNPs could effectively improve the antibacterial activities of some azole complexes exhibiting broad-spectrum biocidal activities toward many different microbial strains. The antibacterial efficacies could be related to the azolyl ring, the metal center and the AgNPs diffusion, but further studies are necessary to elucidate the antibacterial mechanism with combination of AgNPs with metal complexes.

\subsection{Cytotoxicity}

Mammalian cells exposed to AgNPs alone did not evidence signs of cytotoxic effects. The viability assays using 3-(4,5-dimethylthiazol-2-yl)-2,5-diphenyltetrazolium bromide (MTT) reported viabilities higher than $90 \%$. However, the combination of most azole complexes with AgNPs had a deleterious effect, except for compounds 4 and 8 (Figure 4).

The fibroblast viability was always higher than $60 \%$ for all complexes in combination with AgNPs; these values suggest a toxic effect at $50 \mu \mathrm{g} \mathrm{mL}{ }^{-1}$. Although lower doses could be employed in animal studies without losing antibacterial effect, these studies are required to identify the potential $\mathrm{LD}_{50}$ of the compounds with AgNPs [17]. 


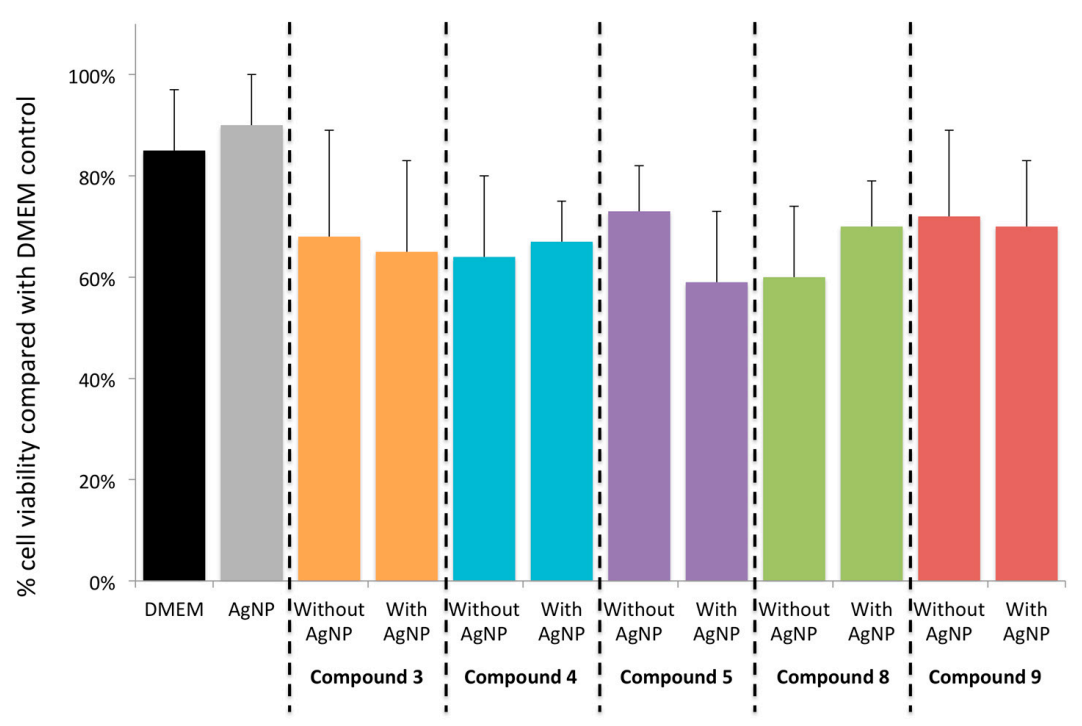

Figure 4. Cytotoxic effects of azole complexes $\left(50 \mu \mathrm{g} \mathrm{mL}^{-1}\right)$ alone and in combination with AgNPs (10-nm diameter at $2 \mu \mathrm{g} \mathrm{mL}{ }^{-1}$ ). The HFF cells were exposed to the complexes and AgNPs for $24 \mathrm{~h}$.

\section{Materials and Methods}

\subsection{General Information}

All manipulations were routinely performed in an inert atmosphere (nitrogen) using standard Schlenk-tube techniques. All reagent-grade solvents were dried, distilled, and stored under a nitrogen atmosphere. The starting compounds were prepared based on the literature: bis(3,5-dimethyl1-pyrazolyl)methane [38], bis(1,2,4-triazol-1-yl)methane [39], 3,5-bis(3,5-dimethylpyrazol-1ylmethyl)toluene [40], 3,5-bis(benzotriazol-1-ylmethyl)toluene [41] and 1,3-bis(indazol-1-ylmethyl) benzene (L). The synthetic protocols for the previously reported complexes dichloro[bis(3,5dimethylpirazol-NN)] cobalt(II) (1), dichloro[bis(3,5-dimethylpirazol-NN)]-copper(II) (2), dichloro[bis (3,5-dimethyl-1-pyrazolyl)methane-NN]cobalt(II) (3), dichloro[bis(3,5-dimethyl-1-pyrazolyl)methaneNN]copper(II) (4), dichloro[bis(1,2,4-triazol-1-yl)methane-NN]-cobalt(II) (9) and dichloro[bis(1,2,4triazol-1-yl) methane-NN]copper(II) (10) are provided in the Supplementary Information [8]. Elemental analyses (C, H and N) were performed with a FLASH 2000 CHNS/O Analyzer (Thermo Fisher Scientific, Waltham, MA, USA). Fourier-transform infrared (FTIR) spectra were recorded on a Thermo Nicolet NEXUS FTIR spectrophotometer (Thermo Fisher Scientific) using KBr pellets Melting points were determined on a Mel-Temp ${ }^{\circledR} 1101 \mathrm{D}$ apparatus (Eletrothermal, Staffordshire, UK) in open capillary tubes, and they are reported uncorrected. Ultraviolet-visible (UV-Vis) spectra were recorded on a Cary 100 spectrophotometer (Agilent Technologies, Kansas City, KS, USA). Thermogravimetric analyses (TGA) of the complexes were obtained on a NETZSCH STA 409 PC/PG from 8 to $10 \mathrm{mg}$ of the complexes in nitrogen media. The samples were subjected to dynamic heating over a temperature range of $30-700{ }^{\circ} \mathrm{C}$ with a heating rate of $10{ }^{\circ} \mathrm{C} \mathrm{min}{ }^{-1}$. The TG curves were analyzed to give the percentage mass loss as a function of the temperature.

\subsection{Synthesis of the Complexes}

\subsubsection{Dichloro[3,5-bis(3,5-dimethylpyrazol-1-ylmethyl)toluene-NN]cobalt(II) (5)}

A solution of 3,5-bis(3,5-dimethylpyrazol-1-ylmethyl)toluene ( $0.33 \mathrm{mmol} ; 101,4 \mathrm{mg})$ in acetonitrile $\left(\mathrm{CH}_{3} \mathrm{CN}, 2 \mathrm{~mL}\right)$ was added to a solution of $\mathrm{CoCl}_{2}(0.38 \mathrm{mmol} ; 49.8 \mathrm{mg})$ in $\mathrm{CH}_{3} \mathrm{CN}(5 \mathrm{~mL})$. The reaction mixture was refluxed for $12 \mathrm{~h}$ and dried under vacuum. A pure blue compound was obtained by crystallization from dichloromethane (DCM). Yield: $128 \mathrm{mg}(89 \%)$. M.p.: $192-193{ }^{\circ} \mathrm{C}$. IR (KBr) v/ $\mathrm{cm}^{-1}$ : 2921m, 1553s, 1468s, 1421s, 1368s, 1271w, 1047m, 799m, 729s. Anal. calc. for $\mathrm{C}_{19} \mathrm{H}_{24} \mathrm{~N}_{4} \mathrm{CoCl}_{2}: \mathrm{C}, 52.07$; 
$\mathrm{H}, 5.52 ; \mathrm{N}, 12.78 \%$. Found $\mathrm{C}, 51.87 ; \mathrm{H}, 5.51 ; \mathrm{N}, 12.72 \%$. UV $/ \mathrm{Vis}\left(\mathrm{CH}_{3} \mathrm{CN}\right): \lambda_{\max } / \mathrm{nm}\left(\varepsilon /\left(\mathrm{L} \cdot \mathrm{mol}^{-1} \cdot \mathrm{cm}^{-1}\right)\right)$ $=225$ (2666), 570 (301), 616 (328), 678 (441).

\subsubsection{Dichloro[3,5-bis(3,5-dimethylpyrazol-1-ylmethyl)toluene-NN]copper(II) (6)}

A solution of 3,5-bis(3,5-dimethylpyrazol-1-ylmethyl)toluene $(0.65 \mathrm{mmol} ; 200.5 \mathrm{mg})$ in acetone $(3 \mathrm{~mL})$ was added to a solution of $\mathrm{CuCl}_{2}(0.65 \mathrm{mmol} ; 87.4 \mathrm{mg})$ in acetone $(5 \mathrm{~mL})$. The reaction mixture was stirred at r.t. for $12 \mathrm{~h}$. A green solid formed and was filtered off, washed with acetone and dried under vacuum. Yield: $251 \mathrm{mg}(87.4 \%)$. M.p.: $185-186^{\circ} \mathrm{C}$. IR (KBr) $v / \mathrm{cm}^{-1}: 3445 \mathrm{w}, 2926 \mathrm{~m}, 1608 \mathrm{~m}$, 1556vs, 1469s, 1424s, 1385s, 1302m, 1055m, 843m, 799m, 786m, 470w. Anal. calc. for $\mathrm{C}_{19} \mathrm{H}_{24} \mathrm{~N}_{4} \mathrm{CuCl}_{2}$ : C, 51.53; H, 5.46; N, 12.65\%. Found C, 51.22; H, 5.25; N, $11.87 \%$. UV/Vis $\left(\mathrm{CH}_{3} \mathrm{CN}\right): \lambda_{\max } / \mathrm{nm}$ $\left(\varepsilon /\left(\mathrm{L} \cdot \mathrm{mol}^{-1} \cdot \mathrm{cm}^{-1}\right)\right)=219(19,666), 275(2974), 355(1369), 454$ (459).

\subsubsection{Dichloro[1,3-bis(indazol-1-ylmethyl)benzene-NN]cobalt(II) (7)}

A solution of 1,3-bis(indazol-1-ylmethyl)benzene $(0.29 \mathrm{mmol} ; 99.6 \mathrm{mg})$ in $\mathrm{CH}_{3} \mathrm{CN}(3 \mathrm{~mL})$ was added to a solution of $\mathrm{CoCl}_{2}(0.30 \mathrm{mmol} ; 38.5 \mathrm{mg})$ in $\mathrm{CH}_{3} \mathrm{CN}(3 \mathrm{~mL})$. The reaction mixture was refluxed for $3 \mathrm{~h}$. A blue solid formed and was filtered off, washed with $\mathrm{CH}_{3} \mathrm{CN}$ and diethyl ether and dried under vacuum. Yield: $91.3 \mathrm{mg}(66.2 \%)$. M.p.: $328{ }^{\circ} \mathrm{C}$. IR $(\mathrm{KBr}) \mathrm{v} / \mathrm{cm}^{-1}: 3094 \mathrm{~m}, 1628 \mathrm{~m}, 1519 \mathrm{~m}, 1438 \mathrm{~m}$, $1310 \mathrm{~m}, 1150 \mathrm{~m}, 1030 \mathrm{w}, 852 \mathrm{~m}, 758 \mathrm{vs}, 740 \mathrm{~m}, 435 \mathrm{w}$. Anal. calc. for $\mathrm{C}_{22} \mathrm{H}_{18} \mathrm{~N}_{4} \mathrm{CoCl}_{2}: \mathrm{C}, 56.43 ; \mathrm{H}, 3.87$; $\mathrm{N}, 11.97 \%$. Found C, $56.19 ; \mathrm{H}, 3.82 ; \mathrm{N}, 11.02 \%$. UV/Vis $(\mathrm{MeOH}): \lambda_{\max } / \mathrm{nm}\left(\varepsilon /\left(\mathrm{L} \cdot \mathrm{mol}^{-1} \cdot \mathrm{cm}^{-1}\right)\right)=275$ (17,343), 294 (14,548), 525 (17).

\subsubsection{Dichloro[1,3-bis(indazol-1-ylmethyl)benzene-NN]copper(II) (8)}

A solution of 1,3-bis(indazol-1-ylmethyl)benzene $(0.59 \mathrm{mmol} ; 199.0 \mathrm{mg})$ in acetone $(5 \mathrm{~mL})$ was added to a solution of $\mathrm{CuCl}_{2}(0.60 \mathrm{mmol} ; 80.7 \mathrm{mg})$ in acetone $(5 \mathrm{~mL})$. The reaction mixture was stirred at r.t. for $12 \mathrm{~h}$. A red solid formed and was filtered off, washed with acetone and dried at $80^{\circ} \mathrm{C}$ for $6 \mathrm{~h}$. Yield: $183 \mathrm{mg}(65.7 \%)$. M.p.: $205^{\circ} \mathrm{C}$. IR (KBr) v/ $\mathrm{cm}^{-1}$ : 3446w, 3098m, 1628m, 1520s, 1431m, 1375m, $1152 \mathrm{~s}, 914 \mathrm{~m}, 755 \mathrm{vs}, 615 \mathrm{w}, 432 \mathrm{w}$. Anal. calc. for $\mathrm{C}_{22} \mathrm{H}_{18} \mathrm{~N}_{4} \mathrm{CuCl}_{2}: \mathrm{C}, 55.82 ; \mathrm{H}, 3.84 ; \mathrm{N}, 11.85 \%$. Found $\mathrm{C}$, $55.80 ; \mathrm{H}, 3.64 ; \mathrm{N}, 11.71 \%$. UV/Vis $(\mathrm{MeOH}): \lambda_{\max } / \mathrm{nm}\left(\varepsilon /\left(\mathrm{L} \cdot \mathrm{mol}^{-1} \cdot \mathrm{cm}^{-1}\right)\right)=275(18,782), 293(16,064)$.

\subsubsection{Dichloro[3,5-bis(benzotriazol-1-ylmethyl)toluene-NN]cobalt(II) (11)}

A solution of 3,5-bis(benzotriazol-1-ylmethyl)toluene $(0.28 \mathrm{mmol} ; 99.5 \mathrm{mg})$ in THF (10 mL) was added to a solution of $\mathrm{CoCl}_{2}(0.31 \mathrm{mmol} ; 40.8 \mathrm{mg})$ in THF $(4 \mathrm{~mL})$. The reaction mixture was refluxed for $20 \mathrm{~h}$. A blue solid formed and was filtered off, washed with THF and diethyl ether and dried at $80^{\circ} \mathrm{C}$ for 12 h. Yield: $111.9 \mathrm{mg}(82.3 \%)$. M.p.: $212-215^{\circ} \mathrm{C}$. IR $(\mathrm{KBr}) v / \mathrm{cm}^{-1}: 3092 \mathrm{w}, 1610 \mathrm{~m}, 1456 \mathrm{~m}$, $1318 \mathrm{~m}, 1229 \mathrm{~m}, 1169 \mathrm{w}, 749 \mathrm{~s}, 434 \mathrm{w}$. Anal. calc. for $\mathrm{C}_{21} \mathrm{H}_{18} \mathrm{~N}_{6} \mathrm{CoCl}_{2}: \mathrm{C}, 52.09 ; \mathrm{H}, 3.75 ; \mathrm{N}, 17.36 \%$. Found C, 52.08; H, 3.66; N, 17.32\%. UV/Vis (DMSO): $\lambda_{\max } / \mathrm{nm}\left(\varepsilon /\left(\mathrm{L} \cdot \mathrm{mol}^{-1} \cdot \mathrm{cm}^{-1}\right)\right)=263(8615), 283(7862)$, 614 (97), 679 (161).

\subsubsection{Dichloro[3,5-bis(benzotriazol-1-ylmethyl)toluene-NN]copper(II) (12)}

A solution of 3,5-bis(benzotriazol-1-ylmethyl)toluene $(0.28 \mathrm{mmol} ; 99.5 \mathrm{mg})$ in acetone $(5 \mathrm{~mL})$ was added to a solution of $\mathrm{CuCl}_{2}(0.28 \mathrm{mmol} ; 37.5 \mathrm{mg})$ in acetone $(5 \mathrm{~mL})$. The reaction mixture was stirred at r.t. for $5 \mathrm{~h}$. A green solid formed and was filtered off, washed with acetone and dried under vacuum. Yield: $116 \mathrm{mg}$ (85.1\%). M.p.: $236-237^{\circ} \mathrm{C}$. IR (KBr) v/ $\mathrm{cm}^{-1}$ : 3131w, 2358w, 2343w, 1609w, 1457m, 1233s, 746vs, 669w, 432w. Anal. calc. for $\mathrm{C}_{21} \mathrm{H}_{18} \mathrm{~N}_{6} \mathrm{CuCl}_{2}$ : C, 51.60; $\mathrm{H}, 3.71 ; \mathrm{N}, 17.19 \%$. Found $\mathrm{C}, 51.24 ; \mathrm{H}$, 3.66; $\mathrm{N}, 17.15 \%$. UV/Vis (DMSO): $\lambda_{\max } / \mathrm{nm}\left(\varepsilon /\left(\mathrm{L} \cdot \mathrm{mol}^{-1} \cdot \mathrm{cm}^{-1}\right)\right)=263(12,769), 284(9667)$.

\subsection{Characterization of $A g N P S$}

Commercial silver nanoparticles with an average diameter of $10 \mathrm{~nm}$ (Cat. 796379 Sigma Aldrich, Waltham, MA, USA) were characterized by dynamic light scattering (DLS) and atomic force microscopy 
(AFM). The hydrodynamic size distribution and zeta potential of the AgNPs were measured in water and solution media by DLS using a Zetasizer Nano ZS system (Model ZEN3600, Malvern Instruments Ltda., Malvern, UK). A suspension of AgNPs were sonicated prior to each measurement. A tip sonicator (Cat. Q700 QSonica, Newtown, CT, USA) was used with a sequence of $20 \mathrm{~s}$ of sonication and $40 \mathrm{~s}$ of rest over $15 \mathrm{~min}$. The sonicated samples were placed into disposable cuvettes (Cat. \#DTS1070, Malvern Instruments). Each sample of AgNPs were measured ten times at room temperature. The refractive index used was 0.056 at a wavelength of $633 \mathrm{~nm}$, and the absorption coefficient was $8.49 \times 10^{-5} \mathrm{~cm}^{-1}$ [42].

\subsubsection{Atomic Force Microscopy (AFM)}

The size distributions and shapes of the particles were measured using an atomic force microscope (Asylum Research MFP-3D Bio, Santa Barbara, CA, USA) with a cantilever operated in tapping mode for image topography. The cantilever was silicon nitride $\left(\mathrm{Si}_{3} \mathrm{~N}_{4}\right)$ with a nominal force constant of $0.06 \mathrm{~N} / \mathrm{m}$. The scan rate was set to $1 \mathrm{~Hz}$ on a scanned area of $2 \mu \mathrm{m}$. The samples were imaged at a preset constant force of interaction of the order of $5 \mathrm{nN}$. The adhesion forces between the tips and the samples, at fixed locations, were determined at the point of disengagement of the tip in the force $(F)$ versus separation $(Z)$ curves (withdraw). Here, the tip experiences a pull-off force $F=k \delta$, where $\delta$ is the deformation at disengagement and $\mathrm{k}$ is the cantilever force constant (ten samples were measured).

\subsubsection{Physicochemical Characterization of the Colloids}

The solutions were prepared in DMSO-Water (1:1) to obtain a concentration equal to $5 \mathrm{mM}$ of complex 9 and $0.005 \mathrm{mg} / \mathrm{mL}$ of AgNPs.

\subsection{In Vitro Antibacterial Activity}

\subsubsection{Reagents}

The solvents used were of analytical grades, and all metal(II) precursors were used as chloride salts. Silver nanoparticles (10 nm (795941) and $30 \mathrm{~nm}$ (795925)) were used as controls and were obtained from Sigma-Aldrich. The 20-nm particles were purchased from US Research Nanomaterials (US1037, Houston, TX, USA) and prepared following the manufacturer's instructions at $100 \mu \mathrm{g} \mathrm{mL}^{-1}$. The metal(II) salts, ligands and metal complexes were prepared as $200 \mathrm{mM}$ solutions in DMSO or dimethylformamide (DMF). Complex 3-5 and $\mathbf{9}$ were dissolved in DMSO at $0.6 \%, 0.6 \%, 0.5 \%$ and $0.7 \%$ respectively. Complex 8 was dissolved in DMF at $0.4 \%$.

\subsubsection{Strains and Isolates}

All metal salts, ligands, metal complexes, AgNPs and AgNPs-complexes were screened in vitro for their antibacterial activities against four Gram-positive (Staphylococcus aureus (ATCC 22923), Methicillin-resistant Staphylococcus aureus (MRSA), Enterococcus faecalis (ATCC 19433) and Bacillus cereus (ATCC 14579)) and four Gram-negative (Escherichia coli (ATCC 25922), Enterobacter aerogenes (ATCC 13048), Salmonella typhimurium (ATCC 14028) and Shigella flexneri (ATCC 29903)) bacterial strains. All strains used were obtained from the American Type Culture Collection (ATCC, Manassas, VA, USA) and stored as glycerol stocks in the Laboratory of Mycology and Phytopathology, at Universidad de los Andes, Bogotá D.C.

\subsubsection{Antibacterial Activities}

For every experiment, each of the bacterial strains were freshly grown from the stored stock in Luria broth (LB)-agar plates (Oxoid, Hampshire, UK) for $24 \mathrm{~h}$ at $30^{\circ} \mathrm{C}$. An inoculum from these plates was used to grow cultures in $5 \mathrm{~mL}$ of LB-media for $24 \mathrm{~h}$ at $250 \mathrm{rpm}$ at $37^{\circ} \mathrm{C}$. For screening, these bacterial cultures were seeded again in fresh LB-media $(1: 12,000)$ for $\sim 3 \mathrm{~h}$ until a concentration of $10^{5}$ $\mathrm{CFU} \mathrm{mL} \mathrm{m}^{-1}\left(0.4-0.5 \mathrm{OD}_{600 \mathrm{~nm}}\right)$ was obtained on a shaker-incubator. A total of $90 \mu \mathrm{L}$ of pre-inoculated 
aliquots $\left(\mathrm{OD}_{600 \mathrm{~nm}}\right.$ of 0.001$)$ were placed into 96-well clear flat-bottom plates (Corning-Costar Corp, Corning, NY, USA) with final volumes of $100 \mu \mathrm{L}$. Bacterial growth kinetics were measured in the 96-well plates at $37^{\circ} \mathrm{C}$ without shaking for 8 and $16 \mathrm{~h}$. Bacteria strains were exposed in parallel for 8 and $16 \mathrm{~h}$ to the complex alone, AgNP alone and, AgNP + Complex independently. The screening of the metal salts, ligands and metal complexes were tested at $500 \mu \mathrm{g} \mathrm{mL}^{-1}$ in triplicate, and the experiments were repeated twice. AgNPs and AgNPs-complexes were screened at three different concentrations $\left(2 \mu \mathrm{g} \mathrm{mL} L^{-1}, 1 \mu \mathrm{g} \mathrm{mL}^{-1}\right.$ and $\left.0.5 \mu \mathrm{g} \mathrm{mL}^{-1}\right)$ maintaining the metal salts, ligands, metal complexes at $500 \mu \mathrm{g} \mathrm{mL}^{-1}$. The compounds used as controls included the antibiotics gentamicin and kanamycin (Roche Diagnostics, Indianapolis, IN, USA), and these were tested at final concentrations of $20 \mu \mathrm{gL}^{-1}$ or $2 \mu \mathrm{g} \mathrm{mL}^{-1}$. All analyses were performed using the GraphPad Prism version 7.02 (GraphPad Software, La Jolla, CA, USA).

\subsubsection{Mammalian-Cell Cytotoxicity Assay}

Primary neonatal human foreskin fibroblasts (HFF) were maintained in Dulbeco's modified Eagle's medium (DMEM) (Sigma, Waltham, MA, USA) supplemented with $5 \%$ or $10 \%$ fetal bovine serum (FBS) (Gibco, Waltham, MA, USA), 1\% penicillin/streptomycin (Gibco) and 2\% glutamine (Gibco). The HFF cells were grown as a monolayer in Roswell Park Memorial Institute (RPMI) 1640 medium (Sigma) supplemented with 10\% FBS (Gibco), 1\% penicillin/streptomycin (Gibco) and 2\% glutamine (Gibco). The cultures were incubated at $37{ }^{\circ} \mathrm{C}$ in a humidified $5 \% \mathrm{CO}_{2}$ atmosphere during two complete cell cycles $(24 \mathrm{~h})$ before treatment.

The cytotoxicity was determined by a colorimetric method based on the reduction of 3-[4,5-dimethylthiazol-2-yl]-2,5-diphenyltetrazolium bromide by viable cells (MTT) described by Mosmann [43]. Briefly, in a 96-well flat-bottom plate, $3 \times 10^{5} \mathrm{HFF}$ cells per well were grown (90\% confluence), with four replicate wells for each treatment and were washed twice in PBS and resuspended in DMEM without FBS. Cells were exposed to two different concentrations of the metal salts, ligands, metal complexes at $500 \mu \mathrm{g} \mathrm{mL}^{-1}$ or $50 \mu \mathrm{g} \mathrm{mL}{ }^{-1}$ at a fixed concentration of $2 \mu \mathrm{g} \mathrm{mL}^{-1}$ for the 10-nm nanoparticles. Cells treated with $10 \%$ DMSO were the positive control, and untreated cells ( $1 \%$ DMSO) served as the negative control. The plate was then incubated at $37{ }^{\circ} \mathrm{C}$ in a humidified $5 \% \mathrm{CO}_{2}$ atmosphere for $24 \mathrm{~h}$. After incubation time, $10 \mu \mathrm{L}$ of MTT $\left(5 \mathrm{mg} \mathrm{mL}^{-1}\right.$ phosphate buffered saline solution) was added to each well, and the cells were incubated for a further $4 \mathrm{~h}$. To dissolve the formazan crystal, $100 \mu \mathrm{L}$ of DMSO were added to each well. Formazan crystals were dissolved by agitation at $37^{\circ} \mathrm{C}$. After $5 \mathrm{~min}$, each well was analyzed in a microplate reader (BioRad, Hercules, CA, USA) at $595 \mathrm{~nm}$ using a reference wavelength of $655 \mathrm{~nm}$. The percentage of viable treated cells was calculated in relation to the untreated controls (viability percentage $=$ OD-treated cells $/$ OD control cells $\times 100 \%$ ). The untreated control was taken as $100 \%$.

\subsubsection{Growth Inhibition of the Bacteria Strains}

Growth inhibition assays were performed as previously described with a slight modification. Briefly, a culture $(5 \mathrm{~mL})$ of bacteria strains were grown from a single colony for $8 \mathrm{~h}$ at $37^{\circ} \mathrm{C}$ in Lysogeny Broth (LB) media and diluted back to an $\mathrm{OD}_{600}$ of 0.001. A 96-well plate assay was set up with $90 \mu \mathrm{L}$ of the respective cultures in LB-media either with DMSO or containing $10-100 \mu \mathrm{g} \mathrm{mL}^{-1}$ of the compounds. The experiment was repeated with and without $2 \mu \mathrm{g} \mathrm{mL} \mathrm{m}^{-1}$ of the $10-\mathrm{nm}$ nanoparticles. The $\mathrm{OD}_{600}$ for all wells was recorded on a Multiskan ${ }^{\mathrm{TM}} \mathrm{GO}$ microplate spectrophotometer (Thermo Scientific ${ }^{\mathrm{TM}}$, Waltham, MA, USA) at $0,8,16$ and $32 \mathrm{~h}$. To assure there were no absorbance contributions from the inhibitors, a change in $\mathrm{OD}_{600}$ was determined by the subtraction of the absorbance from the blank containing an equivalent concentration of inhibitor. The concentration of the compound that inhibited 50\% of the microorganism growth was calculated using the GraphPad Prism version 7.02. 


\section{Conclusions}

In summary, we have synthesized and characterized a series of air-stable cobalt and copper complexes with azole ligand derivatives. Experimental and computational studies predict that all the complexes exhibit a slightly distorted tetrahedral geometry. In vitro assays showed that complexes 3-5, 8 and 9 exhibited moderate antibacterial activities. However, their antibacterial activities increased when combined with AgNPs at a constant concentration of $2 \mu \mathrm{g} \mathrm{mL}{ }^{-1}$, which also impacted the reduction of the azole concentration up to 10 times. The synergistic effect of the azoles and AgNPs did not impact the HFF cellular viability. The complexes combined with AgNPs showed promising activities against different bacterial strains. Further studies to acquire more information concerning their structure-activity relationships are in progress.

Supplementary Materials: The supplementary materials are available online.

Acknowledgments: The authors express their thanks to the Universidad de los Andes for financial support from the Interfaculty project and the Faculty of Sciences. Thanks to Vicerrectoría de Investigaciones Universidad de los Andes and Colciencias Beca Francisco Jose de Caldas 547 for providing financial support to the PhD candidate Fernando Pastrana. We acknowledge the human genetics laboratory Human Genetics Laboratory at Andes University for all their support during the cytotoxicity assays.

Author Contributions: H.F.P., M.F.G., A.M.C. and S.R. performed the in vitro experiments. H.F.P. and A.G.Á. provided the characterization of the AgNPs. N.J.B.-V. carried out the synthesis and characterization of the ligands and complexes. A.M.-C. carried out the DFT computational calculus. All authors contributed with crucial discussions and constructive reviews. J.J.H. is the corresponding author.

Conflicts of Interest: The authors declare no conflict of interest.

\section{Abbreviations}

\begin{tabular}{|c|c|}
\hline AgNPs & Silver nanoparticles \\
\hline WHO & World Health Organization; \\
\hline CDC & Communicable Disease Center \\
\hline FDA & Food and Drug Administration \\
\hline MRSA & Methicillin-resistant Staphylococcus aureus \\
\hline E. aerogenes & Enterobacter aerogenes \\
\hline S. typhimurium & Salmonella typhimurium \\
\hline S. aureus & Staphylococcus aureus \\
\hline E. faecalis & Enterococcus faecalis \\
\hline B. cereus & Bacillus cereus \\
\hline E. coli & Escherichia coli \\
\hline S. flexneri & Shigella flexneri \\
\hline MBC & Minimum Bactericidal Concentration \\
\hline TGA & Thermogravimetric analysis \\
\hline $\mathrm{MIC}_{50}$ & Minimum inhibitory concentration 50 \\
\hline THF & Tetrahydrofuran \\
\hline $\mathrm{CH}_{3} \mathrm{CN}$ & Acetonitrile \\
\hline FTIR & Fourier-transform infrared spectroscopy \\
\hline $\mathrm{HCl}$ & Hydrochloric acid \\
\hline UV-Vis & Ultraviolet-visible spectroscopy \\
\hline $\mathrm{MeOH}$ & Methanol \\
\hline DMSO & Dimethylsulfoxide \\
\hline AFM & Atomic force microscopy \\
\hline PVP & Polyvinylpyrrolidone \\
\hline MTT & (3-(4,5-Dimethylthiazol-2-yl)-2,5-diphenyltetrazolium bromide) tetrazolium \\
\hline DLS & Dynamic Light Scattering \\
\hline $\mathrm{HHF}$ & Human Foreskin Fibroblast \\
\hline $\mathrm{KBr}$ & Potassium bromide \\
\hline DCM & Dichloromethane \\
\hline DMF & Dimethylformamide \\
\hline
\end{tabular}




\section{References}

1. Lok, C.-N.; Ho, C.-M.; Chen, R.; He, Q.-Y.; Yu, W.-Y.; Sun, H.; Tam, P.K.-H.; Chiu, J.-F.; Che, C.-M. Silver nanoparticles: Partial oxidation and antibacterial activities. J. Biol. Inorg. Chem. 2007, 12, 527-534. [CrossRef] [PubMed]

2. Franci, G.; Falanga, A.; Galdiero, S.; Palomba, L.; Rai, M.; Morelli, G.; Galdiero, M. Silver Nanoparticles as Potential Antibacterial Agents. Molecules 2015, 20, 8856-8874. [CrossRef] [PubMed]

3. Naqvi, S.Z.; Kiran, U. Combined efficacy of biologically synthesized silver nanoparticles and different antibiotics against multidrug-resistant bacteria. Int. J. Nanomed. 2013, 8, 3187-3189. [CrossRef] [PubMed]

4. Allahverdiyev, A.M.; Kon, K.V.; Abamor, E.S.; Bagirova, M.; Rafailovich, M. Coping with antibiotic resistance: Combining nanoparticles with antibiotics and other antimicrobial agents. Expert Rev. Anti Infect. Ther. 2011, 9, 1035-1052. [CrossRef] [PubMed]

5. Pelgrift, R.Y.; Friedman, A.J. Nanotechnology as a therapeutic tool to combat microbial resistance. Adv. Drug Deliv. Rev. 2013, 65, 1803-1815. [CrossRef] [PubMed]

6. Zhang, X.-F.; Choi, Y.-J.; Han, J.W.; Kim, E.; Park, J.H.; Gurunathan, S.; Kim, J.-H. Differential nanoreprotoxicity of silver nanoparticles in male somatic cells and spermatogonial stem cells. Int. J. Nanomed. 2015, 10, 1335-1357. [CrossRef]

7. Sass, J.; Heine, L.; Hwang, N. Use of a modified GreenScreen tool to conduct a screening-level comparative hazard assessment of conventional silver and two forms of nanosilver. Environ. Health 2016, 15, 105. [CrossRef] [PubMed]

8. Castillo, K.F.; Bello-Vieda, N.J.; Nuñez-Dallos, N.G.; Pastrana, H.F.; Celis, A.M.; Restrepo, S.; Hurtado, J.J.; Ávila, A.G. Metal Complex Derivatives of Azole: A Study on Their Synthesis, Characterization, and Antibacterial and Antifungal Activities. J. Braz. Chem. Soc. 2016, 27, 1-14. [CrossRef]

9. Singh, K.; Kumar, Y.; Puri, P.; Kumar, M.; Sharma, C. Cobalt, nickel, copper and zinc complexes with 1,3-diphenyl-1H-pyrazole-4-carboxaldehyde Schiff bases: Antimicrobial, spectroscopic, thermal and fluorescence studies. Eur. J. Med. Chem. 2012, 52, 313-321. [CrossRef] [PubMed]

10. Yousef, T.A.; Abu El-Reash, G.M.; Al-Jahdali, M.; El-Rakhawy, E.-B.R. Synthesis, spectral characterization and biological evaluation of $\mathrm{Mn}(\mathrm{II}), \mathrm{Co}(\mathrm{II}), \mathrm{Ni}(\mathrm{II}), \mathrm{Cu}(\mathrm{II}), \mathrm{Zn}(\mathrm{II})$ and $\mathrm{Cd}(\mathrm{II})$ complexes with thiosemicarbazone ending by pyrazole and pyridyl rings. Spectrochim. Acta A Mol. Biomol. Spectrosc. 2014, 129, 163-172. [CrossRef] [PubMed]

11. Pahontu, E.; Fala, V.; Gulea, A.; Poirier, D.; Tapcov, V.; Rosu, T. Synthesis and Characterization of Some New $\mathrm{Cu}(\mathrm{II}), \mathrm{Ni}(\mathrm{II})$ and $\mathrm{Zn}(\mathrm{II})$ Complexes with Salicylidene Thiosemicarbazones: Antibacterial, Antifungal and in Vitro Antileukemia Activity. Molecules 2013, 18, 8812-8836. [CrossRef] [PubMed]

12. Montazerozohori, M.; Mojahedi Jahromi, S.; Masoudiasl, A.; McArdle, P. Nano structure zinc (II) Schiff base complexes of a $N_{3}$-tridentate ligand as new biological active agents: Spectral, thermal behaviors and crystal structure of zinc azide complex. Spectrochim. Acta A Mol. Biomol. Spectrosc. 2015, 138, 517-528. [CrossRef] [PubMed]

13. Atkins, P.W.; Overton, T.; Rourke, J.; Weller, M.; Armstrong, F. Shriver and Atkins' Inorganic Chemistry; Oxford University Press: Oxford, UK, 2010; ISBN 9780199236176.

14. Cotton, F.A.; Wilkinson, G.; Murillio, C.A.; Bochmann, M. Advanced Inorganic Chemistry; Wiley: Hoboken, NJ, USA, 1999. ISBN 9788126513383.

15. Arab Ahmadi, R.; Hasanvand, F.; Bruno, G.; Amiri Rudbari, H.; Amani, S. Synthesis, Spectroscopy, and Magnetic Characterization of Copper(II) and Cobalt(II) Complexes with 2-Amino-5-bromopyridine as Ligand. ISRN Inorg. Chem. 2013, 2013, 1-7. [CrossRef]

16. Navarro-Ranninger, M.C.; Alvarez-Valdés, A.; Camazón, M.J.; Masaguer, J.R. Complexes of copper(II) with substituted benzylideneamines. Inorg. Chim. Acta 1987, 132, 7-10. [CrossRef]

17. Zhou, Y.; Kong, Y.; Kundu, S.; Cirillo, J.D.; Liang, H. Antibacterial activities of gold and silver nanoparticles against Escherichia coli and bacillus Calmette-Guérin. J. Nanobiotechnol. 2012, 10, 19. [CrossRef] [PubMed]

18. Rai, M.; Yadav, A.; Gade, A. Silver nanoparticles as a new generation of antimicrobials. Biotechnol. Adv. 2009, 27, 76-83. [CrossRef] [PubMed]

19. Zhang, Y.; Yang, M.; Portney, N.G.; Cui, D.; Budak, G.; Ozbay, E.; Ozkan, M.; Ozkan, C.S. Zeta potential: A surface electrical characteristic to probe the interaction of nanoparticles with normal and cancer human breast epithelial cells. Biomed. Microdevices 2008, 10, 321-328. [CrossRef] [PubMed] 
20. Honary, S.; Zahir, F. Effect of Zeta Potential on the Properties of Nano-Drug Delivery Systems-A Review (Part 2). Trop. J. Pharm. Res. 2013, 12, 265. [CrossRef]

21. Gottenbos, B.; Grijpma, D.W.; van der Mei, H.C.; Feijen, J.; Busscher, H.J. Antimicrobial effects of positively charged surfaces on adhering Gram-positive and Gram-negative bacteria. J. Antimicrob. Chemother. 2001, 48, 7-13. [CrossRef] [PubMed]

22. Agnihotri, S.; Mukherji, S.; Mukherji, S. Size-controlled silver nanoparticles synthesized over the range 5-100 nm using the same protocol and their antibacterial efficacy. RSC Adv. 2014, 4, 3974-3983. [CrossRef]

23. Elechiguerra, J.L.; Burt, J.L.; Morones, J.R.; Camacho-Bragado, A.; Gao, X.; Lara, H.H.; Yacaman, M.J. Interaction of silver nanoparticles with HIV-1. J. Nanobiotechnol. 2005, 3, 6. [CrossRef] [PubMed]

24. Nair, L.S.; Laurencin, C.T. Silver Nanoparticles: Synthesis and Therapeutic Applications. J. Biomed. Nanotechnol. 2007, 3, 301-316. [CrossRef]

25. Van den Bossche, H.; Willemsens, G.; Cools, W.; Marichal, P.; Lauwers, W. Hypothesis on the molecular basis of the antifungal activity of N-substituted imidazoles and triazoles. Biochem. Soc. Trans. 1983, 11, 665-667. [CrossRef] [PubMed]

26. Herbrecht, R. Voriconazole: Therapeutic review of a new azole antifungal. Expert Rev. Anti Infect. Ther. 2004, 2, 485-497. [CrossRef] [PubMed]

27. Fang, B.; Zhou, C.-H.; Rao, X.-C. Synthesis and biological activities of novel amine-derived bis-azoles as potential antibacterial and antifungal agents. Eur. J. Med. Chem. 2010, 45, 4388-4398. [CrossRef] [PubMed]

28. Shelke, S.; Mhaske, G.; Gadakh, S.; Gill, C. Green synthesis and biological evaluation of some novel azoles as antimicrobial agents. Bioorg. Med. Chem. Lett. 2010, 20, 7200-7204. [CrossRef] [PubMed]

29. Khabnadideh, S.; Rezaei, Z.; Khalafi-Nezhad, A.; Bahrinajafi, R.; Mohamadi, R.; Farrokhroz, A.A. Synthesis of $\mathrm{N}$-Alkylated derivatives of imidazole as antibacterial agents. Bioorg. Med. Chem. Lett. 2003, 13, 2863-2865. [CrossRef]

30. Bayrak, H.; Demirbas, A.; Demirbas, N.; Karaoglu, S.A. Synthesis of some new 1,2,4-triazoles starting from isonicotinic acid hydrazide and evaluation of their antimicrobial activities. Eur. J. Med. Chem. 2009, 44, 4362-4366. [CrossRef] [PubMed]

31. Heerding, D.A.; Chan, G.; DeWolf, W.E.; Fosberry, A.P.; Janson, C.A.; Jaworski, D.D.; McManus, E.; Miller, W.H.; Moore, T.D.; Payne, D.J.; et al. 1,4-Disubstituted imidazoles are potential antibacterial agents functioning as inhibitors of enoyl acyl carrier protein reductase (FabI). Bioorg. Med. Chem. Lett. 2001, 11, 2061-2065. [CrossRef]

32. Kljun, J.; Scott, A.J.; Lanišnik Rižner, T.; Keiser, J.; Turel, I. Synthesis and Biological Evaluation of Organoruthenium Complexes with Azole Antifungal Agents. First Crystal Structure of a Tioconazole Metal Complex. Organometallics 2014, 33, 1594-1601. [CrossRef]

33. Kabbani, A.T.; Hammud, H.H.; Ghannoum, A.M. Preparation and antibacterial activity of copper and cobalt complexes of 4-chloro-3-nitrobenzoate with a nitrogen donor ligand. Chem. Pharm. Bull. (Tokyo) 2007, 55, 446-450. [CrossRef] [PubMed]

34. Silver, S. Bacterial resistances to toxic metal ions-A review. Gene 1996, 179, 9-19. [CrossRef]

35. Chandra, S.; Raizada, S.; Tyagi, M.; Gautam, A. Synthesis, spectroscopic, and antimicrobial studies on bivalent nickel and copper complexes of bis(thiosemicrbazone). Bioinorg. Chem. Appl. 2007, 2007, 1-7. [CrossRef] [PubMed]

36. Atria, A.M.; Cortés-Cortés, P.; Garland, M.T.; Baggio, R.; Morales, K.; Soto, M.; Corsini, G. X-ray studies and antibacterial activity in copper and cobalt complexes with imidazole derivative ligands. J. Chil. Chem. Soc. 2011, 56, 786-792. [CrossRef]

37. Collin, F.; Karkare, S.; Maxwell, A. Exploiting bacterial DNA gyrase as a drug target: Current state and perspectives. Appl. Microbiol. Biotechnol. 2011, 92, 479-497. [CrossRef] [PubMed]

38. Boni, A.; Pampaloni, G.; Peloso, R.; Belletti, D.; Graiff, C.; Tiripicchio, A. Synthesis of copper(I) bis(3,5-dimethylpyrazolyl)methane olefin complexes and their reactivity towards carbon monoxide. J. Organomet. Chem. 2006, 691, 5602-5609. [CrossRef]

39. Juliá, S.; Sala, P.; Del Mazo, J.; Sancho, M.; Ochoa, C.; Elguero, J.; Fayet, J.-P.; Vertut, M.-C. $\mathrm{N}$-polyazolylmethanes. 1. Synthesis and $\mathrm{nmr}$ study of $N, N^{\prime}$-diazolylmethanes. J. Heterocycl. Chem. 1982, 19, 1141-1145. [CrossRef] 
40. Hurtado, J.; Portaluppi, M.; Quijada, R.; Rojas, R.; Valderrama, M. Synthesis, characterization, and reactivity studies in ethylene polymerization of cyclometalated palladium(II) complexes containing terdentate ligands with N,C,N-donors. J. Coord. Chem. 2009, 62, 2772-2781. [CrossRef]

41. Hurtado, J.; Rojas, R.S.; Pérez, E.G.; Valderrama, M. Palladium complex bearing 3,5-bis(benzotriazol1-ylmethyl)toluene ligand catalyzes oxidative amination of allyl butyl ether. J. Chil. Chem. Soc. 2013, 58, 1534-1536. [CrossRef]

42. Johnson, P.B.; Christy, R.W. Optical constants of the noble metals. Phys. Rev. B 1972, 6, 4370-4379. [CrossRef]

43. Mosmann, T. Rapid colorimetric assay for cellular growth and survival: Application to proliferation and cytotoxicity assays. J. Immunol. Methods 1983, 65, 55-63. [CrossRef]

Sample Availability: Samples of all the compounds are available from the authors.

(C) 2018 by the authors. Licensee MDPI, Basel, Switzerland. This article is an open access article distributed under the terms and conditions of the Creative Commons Attribution (CC BY) license (http:/ / creativecommons.org/licenses/by/4.0/). 